\title{
Psychological profile of female students with a tendency to anorexia nervosa
}

\author{
ANDREI SHPAKOU ${ }^{1, A-F}$, VALERIY KOVALEVSKIY ${ }^{2, A, B, D, F}$, LIUDMILA KLIMATCKAYA ${ }^{3, A-F}$, \\ OLGA ZAITSEVA ${ }^{4, A-E}$, ANNA JANOCHA ${ }^{5, A, ~ D-F}$
}

${ }^{1}$ Department of Sports Medicine and Rehabilitation, Yanka Kupala State University of Grodno, Belarus

${ }^{2}$ Department of Childhood Psychology, Krasnoyarsk Pedagogical University named after V.P. Astafiev, Russia

${ }^{3}$ Department of Social Pedagogy and Social Work, Krasnoyarsk Pedagogical University named after V.P. Astafiev,

Russia

${ }^{4}$ Science-Research Institute of Medical Problems of the North, Russian Academy of Sciences, Siberian Branch, Krasnoyarsk, Russia

${ }^{5}$ Department of Physiology, Wroclaw Medical University, Poland

A - Study Design, B - Data Collection, C - Statistical Analysis, D - Data Interpretation, E - Manuscript Preparation, F - Literature Search, G - Funds Collection

Summary Background. Various authors have analyzed factors determining the appearance of anorexia nervosa and did not reach a consensus. The article presents the results and our opinion that deep psychological problems of individual are the cornerstone of the development of anorexia nervosa.

Objectives. To study the psychological profile of female students with a tendency to anorexia nervosa.

Material and methods. 118 young females aged 16-22 with eating disorders, all citizens of Krasnoyarsk, were examined. According to body mass index (BMI), two groups were formed: group A (78 females with normal BMI), group B ( 40 females with low BMI $<18 \mathrm{~kg} / \mathrm{m}^{2}$ ). The emotional state was determined by the Cattell's 16 PF and EPQ questionnaires. Participants signed informed consent.

Results. Cattell's questionnaire: general individual and typological qualities of all students were revealed. Descriptors of a low range prevailed in group B. Extroversion was significantly lower in group B than in group $A(p<0.001)$. Emotional lability was significantly higher in group $\mathrm{B}$ than in group $\mathrm{A}(p=0.04)$. EPQ questionnaire: in a comparison between group $\mathrm{A}$ and group $\mathrm{B}$, the introversive type among females with $\mathrm{BMI}<18 \mathrm{~kg} / \mathrm{m}^{2}$ was registered more often $(p<0.001)$; emotional instability was higher $(p<0.001)$; and psychoticism was rated as $p=0.01$.

Conclusions. The concept about the existence of options of individual and typological qualities of a person with various BMI was confirmed. A distinctive feature of females with a tendency to anorexia nervosa is an increased frequency of occurrence of the introversive type of personality in combination with a growth of the level of emotional instability and psychoticism and forms neurotic personality traits. Key words: anorexia nervosa, female, students, psychological profile.

Shpakou A, Kovalevskiy V, Klimatckaya L, Zaitseva O, Janocha A. Psychological profile of female students with a tendency to anorexia nervosa. Fam Med Prim Care Rev 2017; 19(4): 399-403, doi: https://doi.org/10.5114/fmpcr.2017.70815.

\section{Background}

Anorexia nervosa (AN) is a psychiatric illness characterized by an intense fear of weight gain, low body weight and a disturbance in the experience of one's own body shape or weight. This condition is also frequently associated with a number of personality traits, which have been implicated in the onset, symptomatic expression and maintenance of eating disorders [1]. Personality disorders are related to poor emotion processing and negative mood states, which are similarly reported in AN [2].

AN was rarely recognized before 1960 . In subsequent years, this condition was recognized more and more often. Although, anorexia nervosa is seen primarily in girls and women, about $5-10 \%$ of cases occur in boys or men [3]. It was also observed that the age when the disease is recognized is lowering. According to Keski-Rahkonen et al. [4], the prevalence of anorexia nervosa is the highest in young females aged $15-20$, and the recurrence of the disease within 5 years is about $66.8 \%$.

Various authors at numerous research sites have analyzed factors determining the appearance of anorexia nervosa and did not reach a consensus. Some of them suggest a psychogenic background of this pathologic condition, while others suggest an environmental or genetic [5] influence, as well as the primary disorder of the hypothalamic-pituitary-adrenal axis with secondary hormonal deficit [6]. Endocrine disorders in AN also refer to the gonads, thyroid and the $\mathrm{GH}$-somatomedin axis [6]. Monteleone et al. [7] observed reduced plasma oxytocin levels in females with AN. In anorexic female's reduced level of circulating oxytocin positively correlated with the avoidance of harm - a personality trait characterized by excessive worrying, pessimism, shyness and being fearful, doubtful and easily fatigued. These findings confirm a dysregulation of oxytocin production in AN and show a disruption of the associations between hormone levels and patients' personality traits, which may have a role in certain deranged behaviors of patients with eating disorders.

Baranowska et al. [6] reported that neuropeptides may play a role in the control of appetite and in the mechanism of hormone release. Neuropeptides, such as beta-endorphin, neuropeptide $Y(N P Y)$, galanin and leptin, may affect the release of hormones. On the other hand, the hormonal status may modulate neuropeptide activity. The neuropeptides mentioned above play an important role in thirst regulation through their influence on the hypothalamic food center. Abnormal activity of neuropeptides may lead to disturbed control of appetite and hormonal dysregulation in eating disorders. 
Lowered blood leptin and neuropeptide-Y levels and disorders in the circadian rhythm of $\beta$-endorphin release have been observed in subjects with anorexia nervosa $[6,8]$.

In recent years, much attention has been directed towards the above-mentioned genetic component related to the polymorphism of the BDNF-270 C/T gene (Brain Derived Neurotrophic Factor Gene), which may influence the personality trait associated with a higher risk of AN [5].

Anorexia nervosa is a serious mental illness, which is associated with an obsession to lose weight, refusal of food and the presence of an expressed fear of gaining weight. It should be emphasized that, to date, there is no unambiguous definition of the disease $[1,2]$.

The highest priority for young people is their appearance, fitness in particular. Particularly acute is the problem of females, many of whom suffer from complexes about their own figures, being overweight and unattractive appearance. Young females try to "improve" their figure by limiting food intake, both in volume and in calories. Eating disorders suggest that they use food as an attempt to deal with their life, which is too painful and unmanageable for them. Eating disorders may become a tendency to anorexia nervosa based on the deep psychological problems of a particular individual [9].

Emotions accompany human thought, behavior and expression, and they also very significantly change the way the world is perceived.

Cannon [cited after 10] was the first to consider emotions as an expression of complex brain activity and indicated a behaviorally strict connection of emotional states with the functioning of the human organs. Normally, emotions are considered important elements of motivation that constitute a more or less fixed "readiness to action" [10].

The American psychologist Titchener [cited after 10] has demonstrated the complexity of emotional phenomena by distinguishing affects (e.g. happiness, hatred), moods (e.g. satisfaction, concern, and compound emotions (e.g. intellectual, moral, religious and esthetic emotions).

In this regard, it is appropriate to estimate the individual and typological properties of the personality and emotional status of young females with a low BMI index and eating disorders.

Hypothesis: female students with the following qualities: isolation, emotional instability, anxiety, low self-control, inadequacy of self-esteem are most predisposed to anorexia nervosa.

\section{Objectives}

To study the psychological profile of female students with a tendency to anorexia nervosa.
Research objectives:

1. Form groups of female students with eating disorders depending on $\mathrm{BMI}$ (with normal and low $\mathrm{BMI}<18 \mathrm{~kg} / \mathrm{m}^{2}$ ).

2. To study the individual-typological qualities of females in the experimental and control groups theough the EPQ and Cattell's 16 PF questionnaires.

3. To conduct a comparative analysis of indicators between groups.

\section{Material and methods}

A total of 118 young females aged 16-22, citizens of Krasnoyarsk, were examined. According to BMI, two groups were formed: group A (78 subjects with normal BMI), group B (40 subjects with low $B M I<18 \mathrm{~kg} / \mathrm{m}^{2}$ ). Participants were included into the study after obtaining informed consent. The emotional state of the 60 females (group A - 40, group B - 20 participants) was determined by Cattell's 16 PF questionnaire. Descriptors in Cattell's 16 Personality Factor Model was adapted from Conn and Rieke [11]. 118 young females were tested via the Eysenck Personality Questionnaire (EPQ) (group A - 78, group B - 40 participants). The Interpretation of the Primary and a few Secondary Factors were pointed [12].

The analysis of data was carried out with use of the statistical package of the program STATISTICA, ver. 6.0 (StatSoft Inc. USA). Statistical analysis of the obtained data was carried out utilizing the nonparametric method [13]. The statistical significance of differences was determined using the Mann-Whitney $\mathrm{U}$ test criterion for quantitative signs. Quantitative parameters (in points) are presented in the form of Me - median, 25-75\%. The statistical importance of distinctions of qualitative signs was estimated by means of criterion $\chi^{2}$ with the amendment of Yeats. The results of research of qualitative signs are presented in the form of absolute and relative percentage, with a confidence interval of $95 \%$. The results were considered statistically significant at a significance value of $p<0.05$.

This investigation was examined and approved of by the Research Ethics Committee of the Science-Research Institute of Medical Problems of the North, Russian Academy of Sciences, Siberian Branch, Krasnoyarsk, Russia.

\section{Results}

We evaluated the personal characteristics of young females with different BMI and eating disorders by Cattell's questionnaire. The results are depicted in Table 1.

General individual and typological qualities of all students were revealed. Descriptors of a low range prevailed in group B.

Table 1. Individually-typological characteristics of young females with normal or low BMI and eating disorders according to Cattell's 16 PF questionnaire (points A-Q4)

\begin{tabular}{|l|l|l|l|l|l|}
\hline \multirow{2}{*}{ Scales according to Cattell's questionnaire } & \multicolumn{2}{l|}{$\begin{array}{l}\text { Group A } \\
n=40\end{array}$} & \multicolumn{2}{l}{$\begin{array}{l}\text { Group B } \\
n=20\end{array}$} & $\begin{array}{l}\text { Statistical significance } \\
\text { by Mann-Whitney (p) }\end{array}$ \\
\cline { 2 - 6 } & Me* & $\mathbf{2 5 - 7 5 \%}$ & Me* & 25-75\% & \\
\hline Warmth [A] & 9.00 & $9.00-10.00$ & 6.76 & $6.00-10.00$ & $p=0.0001$ \\
\hline Reasoning [B] & 9.00 & $7.00-11.00$ & 7.00 & $6.00-10.00$ & $p=0.05$ \\
\hline Emotional stability [C] & 9.00 & $9.00-10.00$ & 7.00 & $6.00-9.00$ & $p=0.0001$ \\
\hline Dominance [E] & 9.00 & $7.00-16.00$ & 9.00 & $8.00-10.00$ & $p=0.5$ \\
\hline Liveliness [F] & 10.00 & $9.00-15.00$ & 7.00 & $4.50-11.50$ & $p=0.01$ \\
\hline Rule- consciousness [G] & 8.00 & $8.00-9.00$ & 6.00 & $6.00-10.00$ & $p=0.001$ \\
\hline Social boldness [H] & 9.00 & $9.00-10.00$ & 7.00 & $6.00-9.00$ & $p<0.001$ \\
\hline Sensitivity [I] & 12.00 & $9.00-14.00$ & 7.00 & $6.00-9.00$ & $p=0.0003$ \\
\hline Vigilance [L] & 9.00 & $7.00-11.00$ & 6.00 & $4.00-10.00$ & $p=0.0001$ \\
\hline Abstractedness [M] & 16.00 & $11.00-18.00$ & 11.00 & $10.00-16.00$ & $p=0.14$ \\
\hline Privateness [N] & 10.00 & $9.00-11.00$ & 7.00 & $6.00-9.00$ & $p<0.001$ \\
\hline
\end{tabular}




\begin{tabular}{|c|c|c|c|c|c|}
\hline \multirow[t]{2}{*}{ Scales according to Cattell's questionnaire } & \multicolumn{2}{|c|}{$\begin{array}{l}\text { Group A } \\
n=40\end{array}$} & \multicolumn{2}{|c|}{$\begin{array}{l}\text { Group B } \\
n=20\end{array}$} & \multirow[t]{2}{*}{$\begin{array}{l}\text { Statistical significance } \\
\text { by Mann-Whitney ( })\end{array}$} \\
\hline & Me* & $25-75 \%$ & $M e^{*}$ & $25-75 \%$ & \\
\hline Apprehension [O] & 9.00 & $9.00-10.00$ & 6.00 & $5.00-6.00$ & $p<0.001$ \\
\hline Self-reliance [Q2] & 11.00 & $9.00-12.00$ & 6.00 & $5.00-7.00$ & $p<0.001$ \\
\hline Perfectionism [Q3] & 10.00 & $9.00-14.00$ & 6.00 & $5.00-7.00$ & $p<0.001$ \\
\hline Tension [Q4] & 11.00 & $9.00-12.00$ & 6.00 & $5.00-7.00$ & $p=0.001$ \\
\hline
\end{tabular}

*Quantitative parameters are presented in the form of Me - median, 25-75\%o.

\begin{tabular}{|c|c|c|c|c|c|c|c|}
\hline \multicolumn{2}{|c|}{$\begin{array}{l}\text { Scale according to the } \\
\text { EPQ questionnaire }\end{array}$} & \multicolumn{2}{|l|}{$\begin{array}{l}\text { Group A } \\
n=78\end{array}$} & \multicolumn{2}{|l|}{$\begin{array}{l}\text { Group B } \\
n=40\end{array}$} & \multicolumn{2}{|c|}{ Statistical significance } \\
\hline \multirow{3}{*}{ 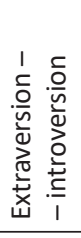 } & Indicators & $\begin{array}{l}\text { Extroverts } \\
\text { [1] }\end{array}$ & $\begin{array}{l}\text { Introverts } \\
\text { [2] }\end{array}$ & $\begin{array}{l}\text { Extroverts } \\
\text { [3] }\end{array}$ & $\begin{array}{l}\text { Introverts } \\
{[4]}\end{array}$ & $c h i^{2}$ & $p\left(c h i^{2}\right)$ \\
\hline & Abs. number & 73 & 5 & 18 & 22 & \multirow{2}{*}{$\begin{array}{l}140.63 \\
72.52 \\
30.08 \\
0.45\end{array}$} & \multirow{2}{*}{$\begin{array}{l}p_{1-2}<0.001 \\
p_{1-3}<0.001 \\
p_{2-4}<0.001 \\
p_{3-4}=0.5\end{array}$} \\
\hline & $\%, \mathrm{Cl}$ & $\begin{array}{l}93.7 \\
86.18-97.23\end{array}$ & $\begin{array}{l}6.3 \\
2.76-13.82\end{array}$ & $\begin{array}{l}45 \\
25.70-65.97\end{array}$ & $\begin{array}{l}55 \\
34.02-74.25\end{array}$ & & \\
\hline \multirow{3}{*}{ 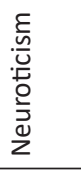 } & Indicators & Low level [1] & Average level [2] & Low level [3] & Average level [4] & \multirow{3}{*}{$\begin{array}{l}13.23 \\
69.83 \\
36.45 \\
0.81\end{array}$} & \multirow{3}{*}{$\begin{array}{l}p_{1-2}=0.001 \\
p_{1-3}<0.001 \\
p_{3-4}<0.001 \\
p_{2-4}=0.3\end{array}$} \\
\hline & Abs. number & 52 & 26 & 6 & 34 & & \\
\hline & $\%, \mathrm{Cl}$ & $\begin{array}{l}65 \\
49.45-77.87\end{array}$ & $\begin{array}{l}35 \\
22.12-50.51\end{array}$ & $\begin{array}{l}15 \\
7.15-29.17\end{array}$ & $\begin{array}{l}85 \\
63.25-94.15\end{array}$ & & \\
\hline \multirow{3}{*}{ 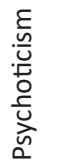 } & Indicators & Low level [1] & High level [2] & Low level [3] & High level [4] & \multirow{3}{*}{$\begin{array}{l}140.63 \\
86.28 \\
6.05\end{array}$} & \multirow{3}{*}{$\begin{array}{l}p_{1-2}<0.001 \\
p_{1-3}<0.001 \\
p_{3-4}=0.014\end{array}$} \\
\hline & Abs. number & 73 & 5 & 14 & 26 & & \\
\hline & $\%, \mathrm{Cl}$ & $\begin{array}{l}93.7 \\
86.18-97.23\end{array}$ & $\begin{array}{l}6.3 \\
2.76-13.82\end{array}$ & $\begin{array}{l}35 \\
18.10-56.96\end{array}$ & $\begin{array}{l}65 \\
43.03-81.89\end{array}$ & & \\
\hline
\end{tabular}

$\mathrm{Cl}$ - confidence interval (95\%).

The results were statistically significant. Only individually-typological characteristics of females with normal BMI, low BMI and eating disorders in scales $\mathrm{E}(p=0.5)$ and $\mathrm{M}(p=0.14)$ were insignificant.

According to Cattell's view, personality is the manner in which human beings behave in a certain situation. From this perspective, it is possible to infer personality traits based on a set of behaviors, and reciprocally, it is possible to predict how a person would behave in a certain situation by having information about their personality traits [11].

Interpretation of secondary factors according to Cattell's questionnaire showed that the level of Extroversion was significantly lower in group B (Me 11.10; 25-75\% 9.90-13.20) than in group $\mathrm{A}$ (Me 19.68; $25-75 \%$ o $18.40-21.40)(p<0.001)$. The level of emotional lability was significantly higher in group $B$ (Me $11.10 ; 25-75 \%$ 9.90-13.20) than in the group A (Me 2.30; $25-$ $-75 \%$ o 1.70-3.70) (Me 3.50; 25-75\% 2.30-4.90) ( $p=0.04)$. There is coherency, especially in relation to more general terms [11].

We also analyzed the emotional status of young females with different $\mathrm{BMI}$ and eating disorders through the EPQ questionnaire. The results are depicted in Table 2.

An extroverted personality type predominated among the young females in group $A\left(p_{1-2}<0.001\right)$ in comparison with group $\mathrm{B}\left(p_{1-3}<0.001\right)$. The number of extroverted and introverted females with low BMI (group $B$ ) were more or less equal $\left(p_{3-4}=0.5\right)$. The level of extroversion in all subjects was in moderate range of 15-16 points (in the scale of "extroversion-introversion"). These young females were characterized by positive emotions, warmth, activity, gregariousness, assertiveness and excitement. An introverted personality type occurred more often in group $B\left(p_{2-4}<0.001\right)$ than in the group $A$, and its degree was in the range of moderate introversion (9-10 points). They were characterized by restraint and the tendency to self-awareness and inner experiences.
Another factor characterizing the property of the individual is the indicator of emotional instability, as measured by a scale of "neuroticism". An emotionally stable personality type was prevalent among young females with a normal BMI $\left(p_{1-2}=\right.$ 0.001 ). The level of emotional stability was in the range $11-12$ points (average). As for the differences in the frequency of occurrence of emotional instability in the study groups with different BMI, females with decreased BMI showed a growth of emotional instability $\left(p_{1-3}<0.001\right)$. The level of this indicator was in the range of high volatility (16-17 points). Persons with neuroticism were characterized as: self-conscious, impulsive, vulnerable to stress, anxious, hostile and depressed.

Another factor that determines the property of the individual is the indicator of psychoticism, determined in the "psychoticism" scale, which shows an individual's propensity to antisocial behavior, pretentiousness, inadequate emotional reactions, high-conflict, non-contact, self-centeredness, selfishness and indifference. In group A, dominant were persons with low levels of psychoticism (less than 4 points, $p_{1-2}<0.001$ ) in comparison with group $\mathrm{B}\left(p_{1-3}<0.001\right)$. Among young females with low $\mathrm{BMI}$, individuals with elevated levels of psychoticism were registered (more than 6 points, $p_{3-4}=0.014$ ).

Thus, subjects with low BMI were characterized by an increased frequency of the introversive type of personality in combination with a growth in the level of emotional instability and psychoticism. This creates neurotic characteristics of personality and a tendency for development of anorexia nervosa. The results were corroborated by Cattell's method.

\section{Discussion}

Literature demonstrates that the requirements which are imposed by our era towards the physical condition of contem- 
porary persons can be reflected in their mentality $[2,14,15]$. Talks about "ugliness of obesity", critical evaluation of appearance by peers and sneers concerning "surplus" injure the sensitive person and become a basis for the formation of the super valuable idea of achievement of "an appearance standard" [14]. Thus, the negative moment is that $34 \%$ of investigated students with eating disorders have low BMI. Anorexia nervosa is generally a disease of young females who, for one reason or another, are not satisfied with their figure. As a rule, psycho-emotionally excitable females of high intelligence, a predilection to depression, kleptomania and phobias suffer from anorexia [15].

The pathogenesis of AN remains still unclear. It has been reported that neuropeptides may play a role in the control of appetite and hormone release, contributing to hormonal disturbances in AN. However, the question if neuropeptide alterations are a consequence or cause of malnutrition is still unresolved [8]. Development of an illness also depends on genetic predisposition, features of the person, mental and physical development, emotions, education and microsocial factors $[5,16]$. Human emotions are also important in AN. According to Zimbardo and Gerrig [16], emotions regulate relationships among people and support pro-social behavior. They are part of our nonverbal communication system, and additionally, they play an important role in regulating social interactions. The specific function of emotions as regulatory processes exists in a broadly understood evaluation that may involve the course of both cognitive and adaptation processes. Being aware of one's own emotional processes allows for management of behavior in particular situations, fundamental to understanding and knowing oneself and in shaping emotional maturity. This is achieved in the course of constructive dealings with random events under the influence of environmental impact or contacts with other people. We may claim that emotions make us human in the humanistic sense of the word.

Having analyzed personal and typological qualities of young females with eating disorders and normal BMI (group A) or low BMI (group B) through Eysenck's (EPQ) and Cattell's questionnaires, we obtained the following results.

General individual and typological qualities of all female students were revealed by Cattell's questionnaire (Table 1). Descriptors of a low range prevailed in group $B$. Emotional lability was significantly higher in group $\mathrm{A}$ than in group $\mathrm{B}(p=0.001)$. According to the EPQ questionnaire (Table 2), a comparison between group A and B was made: introversive type $(p<0.001)$, higher emotional instability $(p<0.001)$, and psychoticism ( $p=$ $0.014)$ were registered more often among subjects with $\mathrm{BMI}$ $<18 \mathrm{~kg} / \mathrm{m}^{2}$ (group B). Similar results of psychoticism were noticed by Miotto et al. [17]. Recent findings also suggested that young females with an eating disorder were significantly more often insecurely attached, emotionally unstable, less extraverted and showed less positive family functioning [18].
The results obtained by the methods of EPQ and Cattell (global factors) were unidirectional. It was shown that group B with $\mathrm{BMI}<18 \mathrm{~kg} / \mathrm{m}^{2}$ had a higher prevalence of emotional lability and introversion. We came to the conclusion that for them, isolation, emotional instability, ignoring social norms, dependence on general judgement, and low self-assessment is peculiar. These qualities create an emotional status with a high level of emotional instability and psychoticism and a rise of frequency of occurrence of an introversive type of personality that leads to the formation of neurotic characteristics of the personality. Other authors also emphasized that eating disorders seem to be associated with high levels of neuroticism [19]. Personality disorders are common in eating disorders, and preliminary reports indicate that this type of disorder implicates a poor prognosis in anorexia nervosa. According to Díaz Marsá et al. [19], the most frequent personality disorders in anorexia nervosa seems to be avoidant and dependent in nature.

However, it should be noted that a combination of neuroticism and introversion may be a risk-factor for symptoms of eating disorders in a non-clinical sample of university females [20]. This coincides with the data received by scientists $[16,21]$ while they detected a tendency to anorexia nervosa and to risk factors of its origin.

The present study probably does not cover all aspects of the problem; nevertheless, a widening of knowledge on psychoemotional factors acting as triggers for anorexia nervosa can contribute to the search for new therapeutic solutions and better prevention of this disease. Holistic care of the patients, taking into account somatic and psychic aspects of diseases, can avail through improving both health state and the quality of life of persons with anorexia nervosa. The methods proposed by the authors (EPQ and Cattell's questionnaires) are simple, inexpensive and easily available, and thus they may serve as a screening examination in early diagnosis of risk-factors for symptoms of eating disorders in non-clinical subjects.

In conclusion, it should be emphasized that a human being constitutes a psychosomatic unity. This fact must never be forgotten in any diagnostic and therapeutic activities.

\section{Conclusions}

The existing concept about the existence of options of individual and typological qualities of persons with varied BMI was confirmed.

A distinctive feature of young females with $\mathrm{BMI}<18 \mathrm{~kg} / \mathrm{m}^{2}$ and eating disorders is an increase in the frequency of occurrence of an introversive type of personality in combination with a growth of the level of emotional instability and psychoticism, isolation, emotional instability, ignoring social norms, dependence on general judgment, low self-assessment. This creates neurotic characteristics of the personality and a tendency for the development of anorexia nervosa.

Source of funding: This work was funded by the authors' own resources.

Conflict of interest: The authors declare no conflict of interests.

\section{References}

1. Halmi KA, Sunday SR, Strober M, et al. Perfectionism in anorexia nervosa: variation by clinical subtype, obsessionality, and pathological eating behavior. Am J Psychiatry 2000; 157(11): 1799-1805.

2. Harrison A, Sullivan S, Tchanturia K, et al. Emotion recognition and regulation in anorexia nervosa. Clin Psychol Psychother 2009; 16(4): 348-356.

3. Barry A, Lippman SB. Anorexia nervosa in males. Postgrad Med 1990; 87(8): 161-168.

4. Keski-Rahkonen A, Hoek HW, Sussex ES, et al. Epidemiology and course of anorexia nervosa in the community. Am J Psychiatry 2007; 164(8): 1259-1265.

5. Rybakowski F, Dmitrzak-Weglarz M, Szczepankiewicz A, et al. Brain derived neurotrophic factor gene Val66Met and -270C/T polymorphisms and personality traits predisposing to anorexia nervosa. Neuro Endocrinol Lett 2007; 28(2): 153-158.

6. Baranowska B, Wolinska-Witort E, Wasilewska-Dziubinska E, et al. The role of neuropeptides in the disturbed control of appetite and hormone secretion in eating disorders. Neuro Endocrinol Lett 2003; 24(6): 431-434. 
7. Monteleone AM, Scognamiglio $\mathrm{P}$, Volpe $\mathrm{U}$, et al. Investigation of oxytocin secretion in anorexia nervosa and bulimia nervosa: relationships to temperament personality dimensions. Eur Eat Disord Rev 2016; 24(1): 52-56.

8. Oświecimska J, Ziora K, Adamczyk $\mathrm{P}$, et al. Effects of neuroendocrine changes on results of ambulatory blood pressure monitoring (ABPM) in adolescent girls with anorexia nervosa. Neuro Endocrinol Lett 2007; 28(4): 410-416.

9. Trotsko ZS, Milayeva DV. Bulimiya i anoreksiya, kak otklonyayushcheyesya povedeniye sovremennoy molodezhi. Vektory razvitiya nauki. Aeterna (Ufa): 2015; 1: 336-340 (in Russian).

10. Lipczyński A. Osobowościowe i biologiczne uwarunkowania samokontroli emocjonalności. Psychiatria OnLine 2002 [cited 20.10.2016]. Available from URL: http//psychiatria.pl/archiwum (in Polish).

11. Conn SR, Rieke ML. The 16PF Fifth Edition technical manual. Champaign, IL: Institute for Personality and Ability Testing; 1994.

12. Bleicher VM. Practical pathopsychology. Practical guide for physicians and honey psychologists. Rostov-Don: Phoenix; 1996 (in Russian).

13. Rebrova OYu. Statisticheskiy analiz meditsinskikh dannykh. Primeneniye paketa prikladnykh programm «STATISTICA». Moskva: Media Sfera; 2002 (in Russian).

14. Ferguson CJ, Muñoz ME, Garza A, et al. Concurrent and prospective analyses of peer, television and social media influences on body dissatisfaction, eating disorder symptoms and life satisfaction in adolescent girls. J Youth Adolesc 2014; 43(1): 1-14.

15. Baryl'nik YUB, Filippova NV, Deyeva MA, et al. Nervnaya anoreksiya i nervnaa bulimiya: ot istorii $k$ sovremennosti. Rossiyskiy psikhiatricheskiy zhurnal 2016; 3: 36-45 (in Russian).

16. Zimbardo PG, Gerrig RJ. Psychologia i życie. Warszawa: Wydawnictwo Naukowe PWN; 2012 (in Polish).

17. Miotto P, Pollini B, Restaneo A, et al. Symptoms of psychosis in anorexia and bulimia nervosa. Psychiatry Res 2010; 175(3): 237-243.

18. Münch AL, Hunger C, Schweitzer J. An investigation of the mediating role of personality and family functioning in the association between attachment styles and eating disorder status. BMC Psychol 2016; 4(1): 36, doi: 10.1186/s40359-016-0141-4.

19. Díaz Marsá M, Carrasco Perera JL, Prieto López R, et al. Role of personality in eating behavior disorders. Actas Esp Psiquiatr 2000; 28(8): 29-36.

20. Miller JL, Schmidt LA, Vaillancourt T, et al. Neuroticism and introversion: a risky combination for disordered eating among a non-clinical sample of undergraduate women. Eat Behav 2006; 7(1): 69-78.

21. Zaitseva O, Klimatskaya L, Kolodyazhnaya T, et al. Features of the emotional status of schoolchildren with different profiles of the lateral phenotype. Puls Uczelni 2014; 8(2): 4-8.

Tables: 2

Figures: 0

References: 21

Received: 16.05.2017

Revised: 17.06 .2017

Accepted: 17.06.2017

Address for correspondence

Andrei I. Shpakou, MD, PhD, Assoc. Prof.

Department of Sports Medicine and Rehabilitation

Yanka Kupala State University of Grodno

22, Ozeshko, Grodno 230023,

Belarus

Tel.: +375(29)78310343

E-mail: shpakofff@tut.by 